\section{OPEN JOURNAL \\ SYSTEMS}

ISSN:2237-2202
Available on line at Directory of Open Access Journals

Journal of Hyperspectral Remote Sensing 03 (2012) 044-054
Journal of Hyperspectral Remote Sensing www.ufpe.br/jhrs

\title{
TEMPORAL ANALYSIS OF THE SURFACE AREA OF URBAN CAMPINA GRANDE WITH LANDSAT 5 TM
}

\author{
Rafael Dantas de Morais ${ }^{*}$ Janaina Barbosa da Silva** \\ * Graduate of Geography of the Federal University of Campina Grande-UFCG, Academic Unit of Geography, Rua \\ Aprígio Veloso, 882, Bairro Universitário, Campina Grande-PB-Brasil. Phone: 55+83 21011000. \\ ${ }^{* *}$ Professor of Federal University of Campina Grande-UFCG, Academic Unit of Geography, Rua Aprígio Veloso, 882, \\ Bairro Universitário, Campina Grande-PB-Brasil. Phone: 55+83 21011000.
}

\begin{abstract}
The thermal variations always have been at the center of discussions in the academy. Some arguments to explain temperature changes as a natural factor or responsibility of human actions has generated great debates and researches that aim to corroborate the defense of each perspective. With technological innovations and the creation of its countless techniques that make possible climate studies currently most accurate and comprehensive, research has become more refined and useful in order to contribute scientifically to actions that benefit the beings dependent on weather conditions for stable their survival. In this perspective, the Remote Sensing contributes essential to support environmental research. The present study aimed to analyze temporally punctual and measured temperatures in the mid of 1989 and 2007 relating to thermal variations occurring with urban growth, the occurrence of El Niño and La Niña and record rainfall in the urban area Campina Grande-PB. The use of satellite images to understand the thermal dynamics of the study area proved to be very useful tool, however, however, emphasizes the need to relate other climatic factors such as extreme events and the incidence observed in the rainfall collection dates image.
\end{abstract}

Keywords: Remote Sensing, Surface Temperature, Climate Change.

\section{Introduction}

Variations thermal phenomena are studied from when it began to conduct research on the environmental temperature. Human actions affect the environment and consequently the thermal variations may cause an increase or decrease of temperature in given area indicator reflecting how some imbalances or natural tendencies. Several scientists have argued tirelessly that question, which is marked by adverse opinions, both in the degree of human interference (scale spacetime) as possible in cooling or warming of the globe. Molion (2008) questions whether the observed warming is natural or anthropogenic causes really, because he says there is evidence that the climate from about 800-1200 before the present, was warmer than today, where man interfered much less. This also reports that climatic variations over the last 
150 years the climate warmed again after cooling.

According to the Intergovernmental Panel on Climate Change-IPCC in its fourth assessment report has been global warming (IPCC, 2007). Its causes are closely related to the increased concentration of carbon dioxide, the main transmitter is the activity of burning fossil fuels derived from oil in cars and also the change in land use, where deforestation is intrinsic condition of vegetation and man the main agent.

Researchers like Hieb \& Hieb (2006) claim that water vapor is a greenhouse gas on Earth more significant, accounting for about $95 \%$ of the greenhouse effect, becoming almost negligible human interference.

Technological advances in particular the use of Remote Sensing that according Novo (2010) consists of:

Joint use of sensors, data processing equipment, data, transmission equipment placed on board aircraft, or other platforms, with the aim of studying events, phenomena and processes occurring on the surface of planet Earth from the record and analysis interactions between electromagnetic radiation and substances that compose in its various manifestations.

This new technique innovated a way to study the countryside and among the benefits that you can point brought capturing information insensitive to the human eye as the spectral range from 10.4 to $12.5 \mu$. The band 6 of Landsat 5 TM thermal known as band, according to the Brazilian Satellite Images (ENGESAT, 2011) shows sensitivity to phenomena related to thermal contrasts, serving to detect thermal properties of rocks, soil, vegetation and water. Importantly, since this satellite into orbit, studies on temperature are performed, and a database was created allowing temporal analysis of various regions with the use of Remote Sensing.

In this perspective, and with the use of Remote Sensing held punctual temporal analysis of temperatures based on Landsat 5 TM for July 1989 and August 2007. Marked out by the temperatures measured was possible effect relationship with urban growth in urban Campina Grande, because according Florenzano (2007), man's actions are primarily responsible for the formation of the phenomenon 'heat islands' (Figure 1) which according with Lombardo (1985) explains the temperature increase in urban areas.

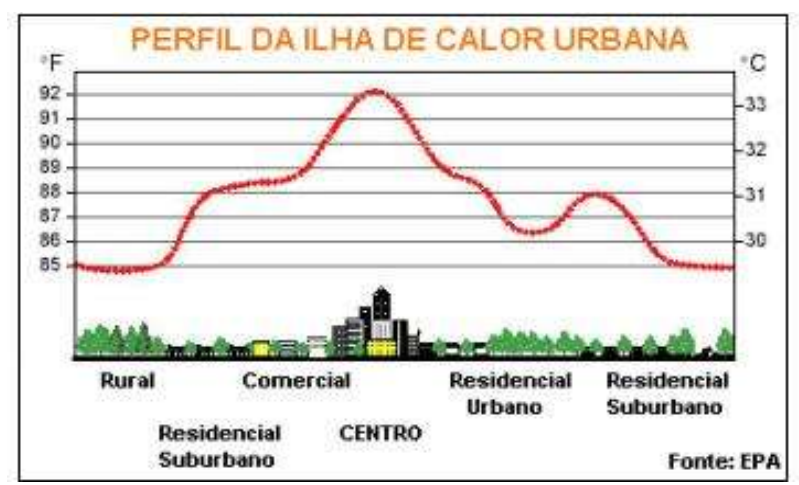

Figure 1: Profile of the urban heat island Source: EPA website cited Bias, Baptista \& Lombardo (2003).

Due to unstable weather condition, it was necessary to make relations between the temperature measured by remote sensing and the El Niño and La Niña, (phenomena operating in the region) according to Oliveira (2001) ocean-atmospheric phenomena are 
characterized by the heating and cooling of surface waters in tropical Pacific Ocean that can dramatically affect regional and global climate due to the following: change in direction of the winds, changes in rainfall patterns in the tropics and mid-latitudes, and depending on the intensity can alter the very dynamics of local temperature.

It was necessary to relate the temperature measured by the Remote Sensing and rainfall, because the variation in this index turns on the variations of moisture that is detected by the Landsat 5 as New (2010). Given the capability to detect satellite moisture and second Jensen (2011) that the water has thermal conductivity greater than any substance and a frame where image capture is performed during the day in the study area leading to the increased extrapolation thermal, the high incidence rainfall may affect the assessments about the temporal temperature.

According to Diniz (2009) Campina Grande is a medium-sized city and showed significant growth in recent years, where it was in the decades from 1940 to 1960 accelerated continuous surge in cotton production which served as a springboard for this expansion. Therefore, in the situation of the previous growth of the City and feasibility of obtaining data considered in the survey, the study area reveals a sample quite feasible to achieve expected results.

\section{Material and Methods}

\subsection{Characterization and Location of Study} Area.

The city of Campina Grande is situated in arid Paraíba mesoregion between the coordinates $7^{\circ}$ 13'39 "S and $35^{\circ}$ 53'24" WGR. According to the 2010 census the municipality has a population of 385,213 inhabitants in a territorial unit of $594.179 \mathrm{~km}^{2}$ (IBGE, 2010). The specific area of study is limited to the one understood by the urban neighborhoods of Campina Grande that has territorial unit of approximately 52.8 square kilometers or approximately $9 \%$ of the city area (Figure 2).

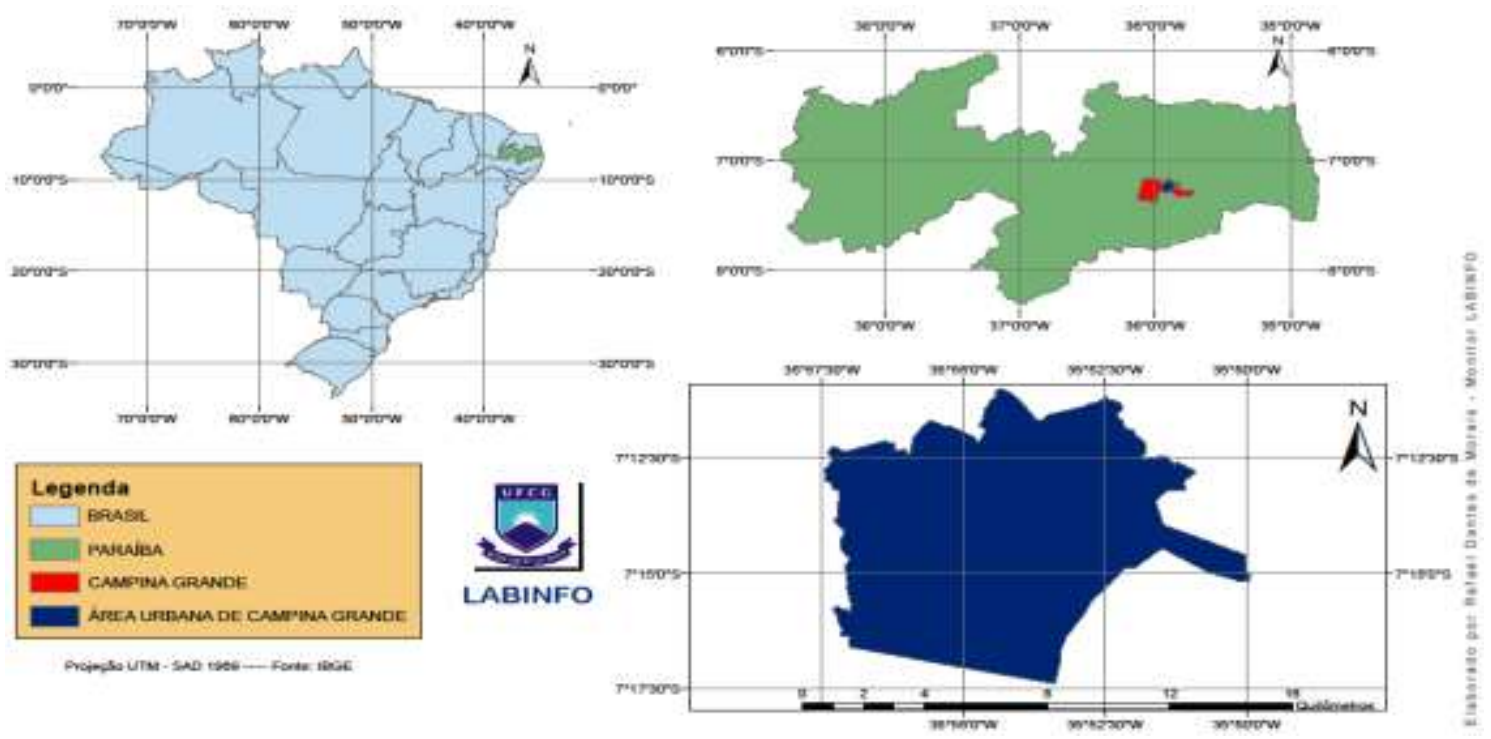

Figure 2: Location of the study area. 


\subsection{Methodological Procedures}

To conduct the survey, considering the Remote Sensing as a tool studies, we opted for the following: a) survey of references, b) preprocessing and processing of satellite images, c) organization of data.

\subsubsection{Survey of References}

The survey consists of references in the investigation of concepts and definitions about the man's responsibility for variations in thermal, Remote Sensing and its use as a study tool, the urban density and its consequences to climate change locations; occurrence of $E l$ Niño and La Niña, the quantification of rainfall in the study area and information on the city of Campina Grande.

\subsubsection{Pre-Processing and Processing of}

\section{Satellite Images}

For the pre-processing of satellite images and application of the parameters to calculate the surface temperature was performed in ERDAS Imagine software 2010, licensed by LABINFO - Laboratory of Digital Cartography, GIS and Remote Sensing Center for the Humanities at the Federal University of Campina Grande. The assembly of the final layout was processed by the software ArcGis 10, also licensed to Laboratory.

We used two images from orbit 215 and paragraph 65 of the Thematic Mapper sensor on board the Landsat 5, concerning the dates of 07/10/1989 and 08/29/2007. These pictures that have but a considerable period of approximately 18 years is still comprised in one and the same time of year to minimize the differences resulting from weather seasons throughout the year.

We used the seven bands of Landsat 5 TM where after the overlap of the bands of the images, these were modified World Geodetic System (WGS) 1984 for South American Datum (SAD) established as the regional geodetic system for South America since 1967. The next step was held georeferencing of the two. The process was generated from the tool "Drop Set Point" that uses a satellite image ever recorded of the same point and orbit of the images to be recorded and, through reference points in common in the two images makes up the registry. The base image for the record was acquired on 18.07.1986 and Landsat.org site, which provides page images, ever recorded, but only gets a picture of each point and orbit, after it took place the cutout area to be studied where, merely show only the urban area of Campina Grande where the neighborhoods are comprised of the City. The processing of satellite imagery to quantify changes in the use and occupation of land in the urban area and obtaining the surface temperature of the urban area of Campina Grande was conducted according to the procedures in Table 1. 


\begin{tabular}{|c|c|c|}
\hline $\begin{array}{l}\text { Radiometric } \\
\text { Calibration }\end{array}$ & $\begin{array}{l}\mathrm{L}_{\lambda_{\mathrm{i}}}=\mathrm{a}_{\mathrm{i}}+\frac{\mathrm{b}_{\mathrm{i}}-\mathrm{a}_{\mathrm{i}}}{255} \mathrm{ND} \\
\text { (Equation } \\
\text { proposed } \quad \text { by } \\
\text { Baker } \quad \& \\
\text { Markham, } \\
\text { 1987). }\end{array}$ & $\begin{array}{l}\text { It consists in } \\
\text { computing the } \\
\text { radiation of each } \\
\text { spectral band (), } \\
\text { wherein the digital } \\
\text { number (ND) of } \\
\text { each pixel of the } \\
\text { image is converted } \\
\text { to monochrome } \\
\text { spectral radiance. A } \\
\text { and B are the } \\
\text { minimum and } \\
\text { maximum spectral } \\
\text { radiances ei } \\
\text { corresponds bands } \\
(1,2, \ldots, 7) \text { Landsat } \\
5 \text { - TM. }\end{array}$ \\
\hline Reflectance & $\begin{array}{l}\rho_{\lambda_{\mathrm{i}}}=\frac{\pi \cdot \mathrm{L}_{{ }_{\mathrm{i}}}}{\mathrm{k}_{\lambda \mathrm{i}} \cdot \cos Z \cdot \mathrm{d}_{\mathrm{r}}} \\
\text { (Equation } \\
\text { proposed by } \\
\text { Bastiaanssen et } \\
\text { al. 1995; Allen } \\
\text { et al., 2002, } \\
\text { Silva et al. } \\
\text { 2005). }\end{array}$ & $\begin{array}{l}\text { It is understood as } \\
\text { the ratio between } \\
\text { the flux of reflected } \\
\text { solar radiation and } \\
\text { the solar radiation } \\
\text { flux incident. is the } \\
\text { spectral radiance of } \\
\text { each band, is the } \\
\text { spectral irradiance } \\
\text { in each band at the } \\
\text { top of the } \\
\text { atmosphere, } \mathrm{Z} \text { is a } \\
\text { solar zenith angle, } \\
\text { and is the square of } \\
\text { the ratio between } \\
\text { the average Earth- } \\
\text { Sun distance (ro) } \\
\text { and the distance } \\
\text { Earth-Sun (r). }\end{array}$ \\
\hline $\begin{array}{l}\text { SAVI - Soil } \\
\text { Adjusted } \\
\text { Vegetation } \\
\text { Index. }\end{array}$ & $\begin{array}{l}S A V I=\frac{(1+\mathrm{L})\left(\rho_{\mathrm{IV}}-\rho_{\mathrm{v}}\right)}{\left(\mathrm{L}+\rho_{\mathrm{IV}}+\rho_{\mathrm{v}}\right)} \\
(\text { Index } \\
\text { Proposed by } \\
\text { Huete, 1988). }\end{array}$ & $\begin{array}{l}\text { It is an index that } \\
\text { seeks to mitigate } \\
\text { the effects of } \\
\text { "background" soil. } \\
\mathrm{L} \text { is constant and its } \\
\text { value is more } \\
\text { frequent } \mathrm{L}=0.5 \\
\text { segundoHuete \& } \\
\text { Warrick, 1990; } \\
\text { Accioly et al., 2002; } \\
\text { Boegh et al., 2002. }\end{array}$ \\
\hline $\begin{array}{l}\text { IAF - Índice } \\
\text { de Área } \\
\text { Foliar ou } \\
\text { LAI - Leaf } \\
\text { Area Index. }\end{array}$ & $\begin{array}{l}\text { IAF }=-\frac{\ln \left(\frac{0,69-\mathrm{SAVI}}{0,59}\right)}{0,91} \\
\text { (Índice } \\
\text { Proposto por } \\
\text { Allen et al. } \\
\text { 2002). }\end{array}$ & $\begin{array}{l}\text { The index is a ratio } \\
\text { of leaf area of all } \\
\text { vegetation per unit } \\
\text { area utilized by } \\
\text { such vegetation. } \\
\text { Sendoportanto, an } \\
\text { indicator of } \\
\text { biomass of each }\end{array}$ \\
\hline
\end{tabular}

\begin{tabular}{|c|c|c|}
\hline & & pixel of the image. \\
\hline $\begin{array}{l}\text { Emissivity } \\
\text { ENB }\end{array}$ & $\begin{array}{l}\varepsilon_{\mathrm{NB}}=0,97+0,00331 \text { LAI } \\
\text { (Equation } \\
\text { proposed } \\
\text { Allen et al. } \\
\text { 2002). }\end{array}$ & $\begin{array}{l}\text { To obtain the } \\
\text { surface temperature, } \\
\text { is used inverted } \\
\text { Planck's equation, } \\
\text { valid for a } \\
\text { blackbody. to each } \\
\text { pixel emits on } \\
\text { electromagnetic } \\
\text { radiation as a black } \\
\text { body, there is a } \\
\text { need to introduce } \\
\text { the emissivity of } \\
\text { each pixel in the } \\
\text { spectral domain of } \\
\text { the thermal band, } \\
\text { which is: } 10.4 \text { - } \\
12.5 \text { um. }\end{array}$ \\
\hline $\begin{array}{l}\text { Surface } \\
\text { temperature }\end{array}$ & $\begin{array}{l}\mathrm{T}_{\mathrm{s}}=\frac{\mathrm{K}_{2}}{\ln \left(\frac{\varepsilon_{\mathrm{NB}} \mathrm{K}_{1}}{\mathrm{~L}_{\lambda, 6}}+1\right)} \\
\text { (Equation } \\
\text { proposed by } \\
\text { Allen et al., } \\
\text { 2002, Silva et } \\
\text { al. 2005). }\end{array}$ & $\begin{array}{l}\mathrm{K}_{1}=607,76 \mathrm{Wm}^{-2} \mathrm{sr}^{-1} \mathrm{~mm}^{-1} \\
\text { And are calibration } \\
\text { constants of thermal } \\
\text { band of Landsat 5-T. } \\
\text { To obtain the surface } \\
\text { temperature are used } \\
\text { the spectral radiance } \\
\text { of the band and } \\
\text { thermal emissivity. }\end{array}$ \\
\hline
\end{tabular}

Table 1 - Stages of processing satellite images to quantify changes in the use and occupation of land in the urban area and obtaining the temporal surface temperature of the urban area of Campina Grande.

To quantify changes in the use and occupation of land in the urban area after step described as reflectance was performed unsupervised classification (ISODATA) where initially the image was divided into ten (10) and later after classes to oversee the classification classes decreased for three (03): water or cloud, vegetated area and urbanized area.

Aiming to assess the temporal surface temperature of the urban area of Campina Grande, after the last step described in Table 01 (Surface Temperature) was also performed unsupervised classification (ISODATA) that divided the surface temperature of twenty (20) intervals and after thermal the number of 
intervals supervising decreased to seven (07) ranges were duly colored for easier distinction of temperatures.

\subsubsection{Data Organization}

Two types of data were collected: those related to the occurrence of El Niño and $L a$ Niña between the years 1988 to 2011, available on the website of the Center for Weather Forecasting and Climate Studies (CPTEC), linked to the National Institute for Space Research (INPE) and the data on the volume of rainfall in Campina Grande between the years 1994 and 2011 provided by the Executive Agency for Water Management in the State of Paraíba (AESA). It is worth noting that it was important access to rainfall data from the year 1989, however, the AESA monitoring was conducted only since 1994. However, data were crucial in research, because besides showing the evolution of rain during the years tracked served to associate the temperature measured in 2007 with the volume of rainfall that year.

\subsection{Results and Discussion}

In examining Figure 3 it was observed that there was a high increase in the surface temperature of the study area for the dates studied.
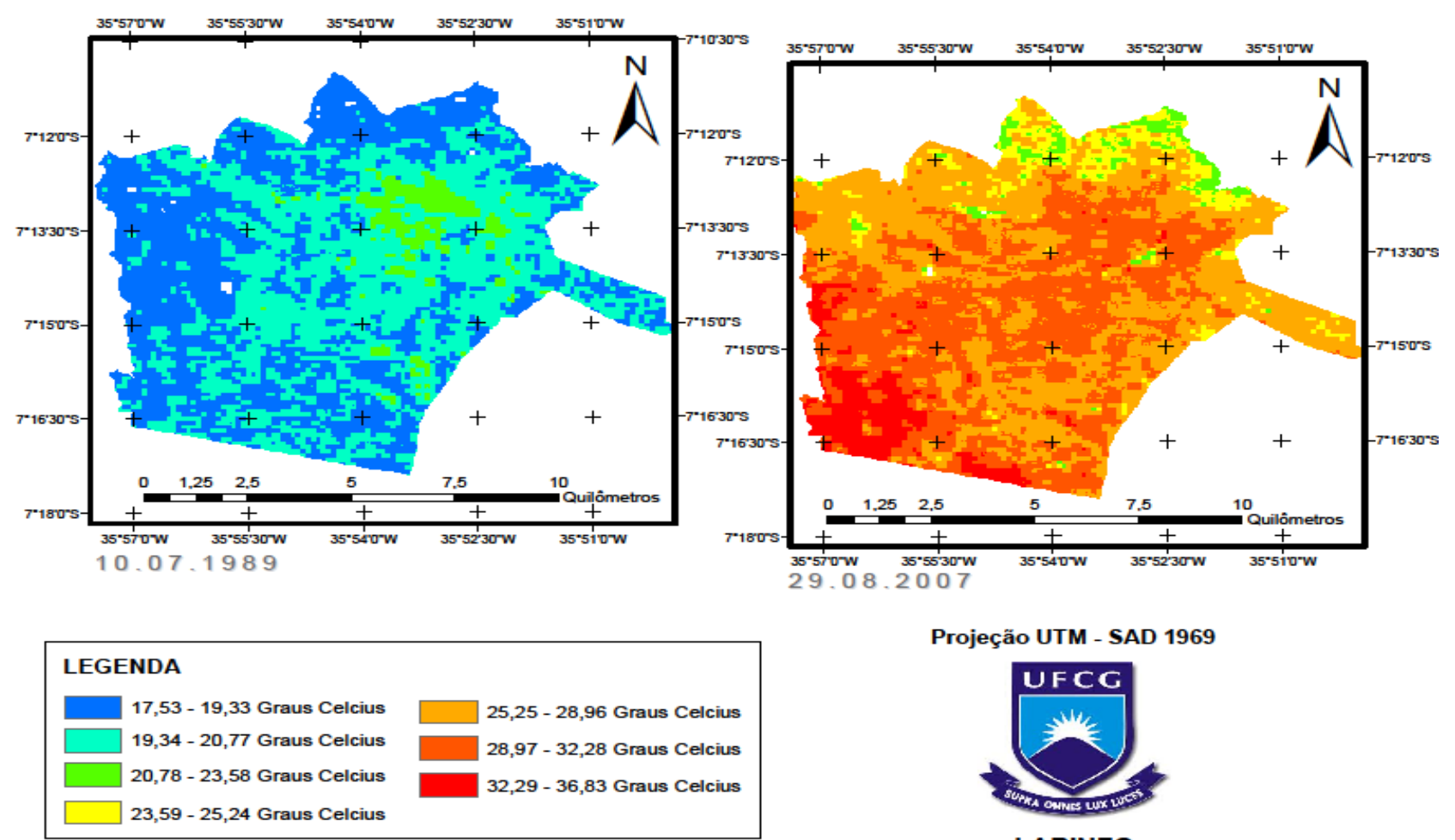

Projeção UTM - SAD 1969

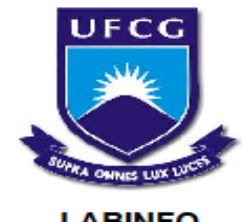

Elaboradopor Rafael Dantas de Morais - rafaeldantas.m@hotmail.com

Figure 3: Thermal Analysis in urban Campina Grande for the years 1987 and 2007.

For the year 1989 the lowest surface highest was $23.58^{\circ} \mathrm{C}$. In 2007 the minimum temperature recorded was $17.53^{\circ} \mathrm{C}$ while the thermal recorded was $20.78^{\circ} \mathrm{C}$ and the 
maximum was $36.83^{\circ} \mathrm{C}$. Therefore, comparing the pictures one can see that the highest surface temperature recorded in 1898 corresponds to the lowest recorded temperature of 2007 and complete the considerable increase in thermal temporal analysis performed. This thermal increase is in line with the predictions of the IPCC (2007) as the temperature increase in different latitudes of the globe.

In the analysis of Figure 4 shows that there was high growth of the urban area of Campina Grande between the years 1989 and 2007 and substantial removal of vegetation.


Projeçăo UTM - SAD 1969

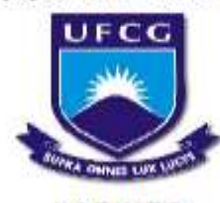

LABINFO

Figure 4: Urban expansion of Campina Grande.

In numbers, in 1989 the urban area temperature. Therefore, this result is in agreement with Leitão et al. (2011) that corresponded to $32 \%$ of the studied range and the vegetated area to $68 \%$. Eighteen (18) years after the urban area accounted for $56 \%$ and the vegetated area showing only $44 \%$ of urban growth beyond the removal of vegetation.

In Campina Grande as increased surface temperature was also demonstrated showed clear influence of urbanization on temperature increase in Petrolina and Juazeiro according to observations made in the period from 01.08.2010 to 31.07.2011.

Table 2 shows the performance of El Niño and La Niña and their intensities (weak, moderate or strong). growth in the urban area and before it was possible to establish a direct relationship between urban sprawl and increasing 


\begin{tabular}{l|l|l|l}
\hline Ano & Fenômeno /Intensidade & Ano & Fenômeno/ Intensidade \\
\hline 1988 & El Niño-Moderado/La Ninã Forte & 2000 & Não Houve \\
\hline 1989 & La Ninã Forte & 2001 & Não Houve \\
\hline 1990 & El Niño- Forte & 2002 & El Niño-Moderado \\
\hline 1991 & El Niño- Forte & 2003 & El-Niño-Moderado \\
\hline 1992 & El Niño-Strong & 2004 & El Niño-Weak \\
\hline 1993 & El Niño-Strong & 2005 & El Niño- Weak \\
\hline 1994 & El Niño-Moderado & 2006 & El Niño- Weak \\
\hline 1995 & El Niño-Moderate/La Ninã- Weak & 2007 & El Niño- Weak /La Niña-Strong \\
\hline 1996 & La Ninã- Strong & 2008 & La Niña-Strong \\
\hline 1997 & El Niño- Strong & 2009 & El Niño- Weak \\
\hline 1998 & El Niño- Strong & 2010 & El Niño- Weak \\
\hline 1999 & There was no & 2011 & La Nina-Strong \\
\hline
\end{tabular}

Table 2: Occurrence and intensity of phenomena El Niño and La Niña between the years 1988 to 2011 - SOURCE: Center for Weather Forecasting and Climate Studies (CPTEC).

Relating the occurrence of these events and their intensities with temperature observed in the urban area of Campina Grande can be seen that in 1989 the event was the active $L a$ Niña strong intensity and temperature measured was relatively low which allows direct relationship between the characteristics of event, because according to the Center for Weather Forecasting and Climate Studies (2011) with the performance of La Niña temperature decreases the Brazilian Northeast. As already explained above, in 2007 measured the temperature was very high compared with 1989 , however, we observed the occurrence of an $\mathrm{El}$ Niño intensity concomitantly with a weak La Niña strong intensity which may have generated unusual weather conditions which prevents the region and create a direct relationship between the phenomenon and safe temperature measured.

As for precipitation in the study area can be seen in Figure 5 the time series between the years 1994 to 2001 concerning millimeters of rain accumulated during all these years. 


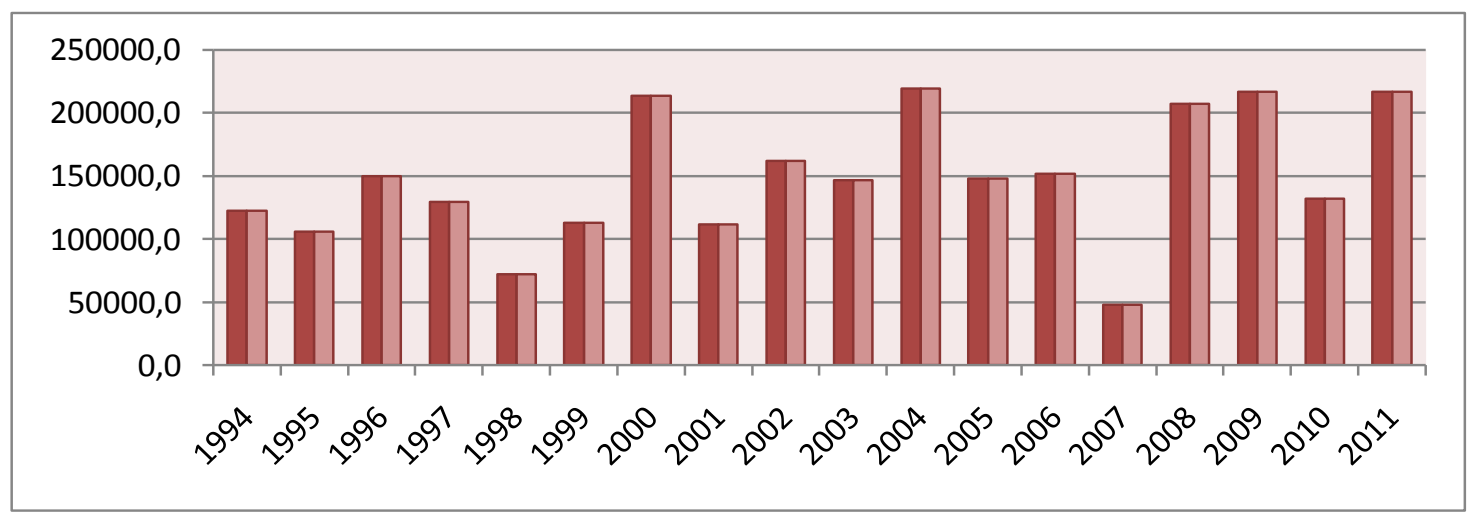

Figure 5: Accumulation of rainfall in the state of Paraíba between the years 1994 and 2011 SOURCE: Executive Agency for Water Management in the State of Paraíba, 2012.

Due to the unavailability of data on rainfall for Campina Grande for the year 1989 was not able to make this year compared with the temperature. However, according to data from the EFSA in 2007 was the year which occurred less rainfall, a fact that undermines establish a direct relationship between temperature and a high volume of water, because the picture shows temperature rise and low rainfall which does not make the saturated soil and therefore not allowed to rising temperatures due to the fact the water has greater carrying capacity and thermal image capture occurs during the day where the temperature tends to rise. (Jensen, 2011).

\section{Conclusions}

Given the above, we attempted to analyze temporally and punctual temperatures measured at mid-year 1989 and 2007 relating to thermal variations occurring with urban growth, the occurrence of El Niño and La Niña and record rainfall in the urban area in Campina Grande-PB.
The term temporal analysis of the urban area of Campina Grande pointed out that during the time delimited increased surface temperature.

The relationship between urban growth and the temperature can be argued that such an expansion can argue the increased thermal surface, because as the temperature increased, there was also growth at the expense of urban vegetation.

Observing the temperature and performance of El Niño and La Niña in the study area for the year 1989 it was possible to establish a direct relationship between these criteria, because as the temperature turns out to be low active phenomenon was that the $L a$ Niña feature is a consequence of its passage and decrease the local temperature of the affected region. However, the number of images analyzed is very small possibly not providing statistical significance.

According to the rainfall data, the year 2007 stands out for being the year with less frequency and volume of rainfall. Therefore, it 
is not possible to directly relate the volume of rainfall with increasing temperature.

\section{Thanks}

The coordination of LABINFO the use of your space and software;

The Prof. Dr, Josicleda Domiciano Galvíncio the exemption in event registration.

The AESA for providing data on precipitation in Campina Grande monitored by the agency from 1994 to 2011.

\section{References}

Agência Executiva De Gestão Das Águas Do Estado Da Paraíba. AESA. (2012). Base De Dados Dos Anos De 1994 A 2011. Campina Grande-PB.

ALLEN, R.; BASTIAANSSEN, W.; WATERS, R.; TASUMI, M.; TREZZA, R. (2002). Surface energy Balance Algorithms For Land (SEBAL), Idaho Implementation Advanced Training Andusers Manual, V. 1.0, 97p.

BASTIAANSSEN, W. G. (1995). Regionalization Of Surface Flux Densities and Moisture Indicators In Composite Terrain - A Remote Sensing Approach Under Clear Skies In Mediterranean Climates. Thesis, Land Bouw Universiteit Wageningen, Netherlands, 273.
SILVA, B. B. DA ; LOPES, G. M.; AZEVEDO, P. V. DE. (2005). Balanço De Radiação Em Áreas Irrigadas Utilizando Imagens LANDSAT 5 - TM. Revista Brasileira De Meteorologia, São Paulo - Sp, V. 20, N. 2, P. 243-252.

Bias, E. De S.; Baptista, G. M. De M.; Lombardo, M. A. (2003). Analise Do Fenômeno De Ilhas De Calor Urbanas, Por Meio Da Combinação De Dados LANDSAt E IKONOS. In: Simpósio Brasileiro De Sensoriamento Remoto, 11., 2003, Belo Horizonte. Anais Xi Sbsr, Belo Horizonte,. P. 1741-1748.

Centro De Previsão De Tempo E Estudos Climáticos/CPTEC

Http://Bancodedados.Cptec.Inpe.Br/, Acesso Em 20.02.2011.

ENGESAT - Empresa Brasileira De Imagens De Satélite - Http://Www.Engesat.Com.Br/, Acesso Em 18.02.2011.

FLORENZANO, T. G. (2002). Iniciação Em Sensoriamento Remoto. São Paulo: Oficina De Textos,. 101p.

HIEB, M.; HIEB, H. (2006). Water Vapor Rulest Hegreen House System.

IPCC AR4/SPM, (2007). Contribution Of Working Group I For The Fourth Assessment 
Report (Ar4), Summary For Policy Makers (Spm), WMO/UNEP, Genebra, Suiça.

HUETE, A.R., (1988). A Soil-Adjusted Vegetation Index. Remote Sensing of Environment. Elsevier Science Publishing Co., NEW YORK, USA. 25:295-309.

LEITÃO, M, DE M, V, B, R.; BEZERRA, P, T, C.; OLIVEIRA, G, M DE.; MENEZES, H, E. (2011). Expansão Urbana E Aumento Da Temperatura Do Ar Nas Cidades De Petrolina/Pe E Juazeiro/Ba. Iv Simpósio Internacional De Climatologia, João Pessoa/PB.
LOMBARDO, M.A. (1985). Ilhas De Calor Nas Metrópoles: O Exemplo De São Paulo. São Paulo: Hucitec.

MARKHAM, B.L.; BARKER, L.L. (1987). Thematic Mapper Bandpass Solar Exoatmospherical Irradiances. International Journal of Remote Sensing, V.8, N.3, P.517523.

MOLION, L, C, B. (2008). Aquecimento Global: Uma Visão Crítica. Revista Brasileira De Climatologia, V. 3/4.

MOLION, L, C, B. (2008). Mitos Do Aquecimento Global. Revista Plenarium, V. 5. 